\title{
Antifungal properties of ethanolic extract and its active compounds from Calocedrus macrolepis var. formosana (Florin) heartwood
}

\author{
Tsair-Bor Yen ${ }^{\mathrm{a}}$, Hui-Ting Chang ${ }^{\mathrm{b}}$, Chun-Chun Hsieh ${ }^{\mathrm{a}}$, Shang-Tzen Chang ${ }^{\mathrm{b}, *}$ \\ ${ }^{a}$ Department of Tropical Agriculture and International Cooperation, National Pingtung University of Science and Technology, Pingtung 912, Taiwan, ROC \\ b School of Forestry and Resource Conservation, National Taiwan University, Taipei 106, Taiwan, ROC
}

Received 22 June 2007; received in revised form 12 September 2007; accepted 15 September 2007

Available online 30 October 2007

\begin{abstract}
The ethanolic extract of Calocedrus macrolepis var. formosana heartwood was screened for antifungal compounds by agar dilution assay and liquid chromatography. Two compounds, $\beta$-thujaplicin and $\gamma$-thujaplicin, responsible for the antifungal property of $C$. macrolepis var. formosana heartwood were isolated by high performance liquid chromatography (HPLC), and identified by ${ }^{1} \mathrm{H} \mathrm{NMR}$ and ${ }^{13} \mathrm{C}$ NMR. The antifungal activities of these two compounds were further evaluated against total 15 fungi, including wood decay fungi, tree pathogenic fungi and molds. The hexane soluble fraction showed the strongest antifungal activities among all fractions. $\beta$-Thujaplicin and $\gamma$-thujaplicin exhibited not only very strong antifungal activity, but also broad antifungal spectrum. The MIC values of $\beta$-thujaplicin and $\gamma$-thujaplicin were in the range of $5.0-50.0 \mu \mathrm{g} / \mathrm{ml}$. In addition, scanning electron microscopy (SEM) was carried out to study the structural change of fungal hyphae induced by $\beta$-thujaplicin. Strong cell wall shrinkage indicated the fungicidal effect could be attributed to the combined actions of metal chelating and cytoplasm leakage. It also suggests that the role of metal chelating is indispensable in the design of environmental-friendly fungicides.
\end{abstract}

(C) 2007 Elsevier Ltd. All rights reserved.

Keywords: Calocedrus macrolepis var. formosana; Antifungal activity; $\beta$-Thujaplicin; $\gamma$-Thujaplicin; Wood extractives

\section{Introduction}

Wood, as a natural organic composite material, is widely used for construction materials and home furnishings, but the unprotected wood is susceptible to wood rotting fungi, resulting in reduction of mechanical strength. Traditional wood preservatives are highly effective against wood decay fungi, but they have been restricted the use in recent years due to their toxicity resulting in environmental hazards. It is also of grave concern in the agriculture practice where the use of traditional agrochemicals has caused seriously environmental pollution to our ecosystem. Consequently, developing environmental-friendly fungicides becomes undoubtedly needed.

\footnotetext{
* Corresponding author. Tel.: +88623366 4626; fax: +8862 23654520 E-mail address: peter@ntu.edu.tw (S.-T. Chang).
}

Discovering the natural fungicides from wood species have attracted much attention of researchers (Rudman, 1965; Kinjo and Yata, 1986; Kondo and Imamura, 1986; Asada et al., 1989; Hart, 1989; Kishino et al., 1995; Kai, 1991; Nabeta et al., 1992; Morita et al., 1997; Chang et al., 1998, 1999, 2000; Schultz and Nicholas, 2000; Inamori et al., 2000; Chang and Cheng, 2002; Wang et al., 2005; Cheng et al., 2006). Results obtained from those previous studies indicate that the bioactive compounds having antifungal properties are effective against wide variety of fungi.

There are many endemic tree species in Taiwan due to its unique ecosystem. Several endemic trees in Taiwan have been studied for their bioactivities. Results obtained from our previous studies showed that Taiwania cryptomerioides, Cinnamomum osmophloeum, and Cryptomeria japonica possessed significant antifungal and antitermitic activities 
(Chang et al., 1998, 1999, 2001; Chang and Cheng, 2002; Cheng and Chang, 2002). Among those species, Calocedrus macrolepis var. formosana (Florin) is one of the most valuable trees and grows at elevations of $800-1500 \mathrm{~m}$ in the north central mountain region of Taiwan. Calocedrus is named for its beauty and abundant resin, and it is also well recognized by their durability, and an incense-like smell. The shonanic acid in its essential oil was first investigated in 1932 by Ichikawa (Lo and Lin, 1956) and more than 50 compounds have been isolated (Lin et al., 1956; Cheng et al., 1961; Fang et al., 1985, 1987, 1989). Antitermitic and antifungal activities of its leaf essential oil have been examined by Cheng et al. (2004). T-muurolol and $\alpha$-cadinol were identified as the major constituents responsible for its antifungal and antitermitic properties. Recently, four novel compounds, calocedimers A, B, C, and D from the bark of $C$. marolepis var. formosana were identified (Hsieh et al., 2006). However, the novel compounds have not been studied for their bioactivities.

Although essentials oils of $C$. macrolepis var. formosana have been shown to have strong antifungal and antitermite activities, to our best knowledge, there is no research investigating the antifungal properties of ethanolic extractives and the antifungal compounds from the heartwood of the endemic tree, C. macrolepis var. formosana. For this reason, the study was to isolate and identify the antifungal compounds from the ethanolic extract of $C$. macrolepis var. formosana heartwood, and evaluated their antifungal activities against wide variety of fungi, including wood decay fungi, plant pathogenic fungi and molds. In addition, the structural alteration on fungal hyphae caused by the antifungal compounds was also examined by scanning electron microscopy.

\section{Methods}

\subsection{Samples of C. macrolepis var. formosana}

The samples of $C$. macrolepis var. formosana were collected in September 2003 from the Lien Hua-Chin Research Center located in Nantou County in central Taiwan. The species was identified and voucher specimens were deposited at the laboratory of wood chemistry (School of Forestry and Resource Conservation, National Taiwan University). In order to remove the excessive moisture that might affect the extractive efficacy, samples were dried at ambient temperature for 5 days (moisture content: $20 \pm 2 \%$, based on oven dry weight) prior to the process of organic solvent extraction.

\subsection{Preparation of plant extraction, isolation and identification}

Heartwood of C. macrolepis var. formosana (10 kg d.w.) were grounded into particles with the diameter size of $0.10 \pm 0.05 \mathrm{~mm}$, and soaked in $95 \%$ ethanol at ambient temperature for 7 days. The ethanolic extract was dec- anted, filtered and concentrated by a rotary evaporator. The dried extract was then separated into $n$-hexane $\left(n-\mathrm{C}_{6} \mathrm{H}_{14}\right)$, ethyl acetate (EtOAc), and ethanol (EtOH) soluble fractions by liquid-liquid partition. The excessive solvent in each partitioned fraction was removed by a rotary evaporator. The $n$-hexane soluble fraction was further divided into 20 subfractions by liquid chromatography in an open column with silica gel 60 (Merck, Darmstadt, Germany). The column was eluted with gradient $n-\mathrm{C}_{6} \mathrm{H}_{14} /$ EtOAc from $98 / 2$ to $0 / 100$. The dried subfractions were grouped by thin layer chromatography (TLC) with silica gel 60 coating. High performance liquid chromatography (HPLC) with a semi-preparation column (silica gel 60) was used to isolate and purify the antifungal compounds (mobile phase: $n$-hexane/EtOAc $=80 / 20$; flow rate $=$ $2.8 \mathrm{ml} / \mathrm{min}$; temperature: $25^{\circ} \mathrm{C}$; total retention time: $30 \mathrm{~min})$. Each isolated compound was purified by repeating the same HPLC process twice prior to the structural analysis by ${ }^{1} \mathrm{H}$ NMR and ${ }^{13} \mathrm{C}$ NMR.

\subsection{Fungal strains}

The fungal strains used in the study were provided from the Bioresource Collection and Research Center (BCRC) of the Food Industry Research and Development Institute (Taiwan). Total 15 fungal strains were listed as follows:

White rot fungi: Lenzites betulina (BCRC 35296), Trametes versicolor (BCRC 35253), Schizophyllum commune (BCRC 35328), and Pycnoporus coccineus (BCRC 36772). Brown rot fungi: Laetiporus sulphureus (BCRC 35305), Phaeolus schweinitzii (BCRC 35365), Gloeophyllum trabeum (BCRC 31614), and Fomitopsis pinicola (BCRC 35303). Pathogenic fungi: Fusarium solani (BCRC 32458), Pestalotiopsis funerea (BCRC 35266), Colletotrichum gloeosporioides (BCRC 31605), and Ganoderma australe (BCRC 35394). Molds: Aspergillus niger (BCRC 32073), Penicillium citrinum (BCRC 32850), and Trichoderma viride (BCRC 33129).

\subsection{Antifungal assays}

Antifungal assays were performed as described previously (Chang et al., 1999, 2000) with slight modifications. Dried fractions, purified compounds and propiconazole were dissolved in ethanol separately. A commercial fungicide, propiconazole, was used as the comparison. Solutions of serial concentrations of chemicals were mixed with sterilized potato dextrose agar (PDA) in Petri dish $(9 \mathrm{~cm}$ diameter) containing $15 \mathrm{ml}$ agar, when the agar was still in liquid form. After inoculating the mycelia of fungus onto the center of solidified agar, the dishes were incubated in the dark at $26 \pm 2{ }^{\circ} \mathrm{C}$ and $70 \%$ relative humidity. When the mycelium of fungi reached the edges of the control dishes, the antifungal indices were calculated. Each test was repeated five times and the values were averaged. The formula for calculating antifungal index is shown as follows: 
Antifungal index $\%=\left(1-D_{\mathrm{a}} / D_{\mathrm{b}}\right) \times 100$

where $D_{\mathrm{a}}$ is the diameter of growth zone in the experimental dish $(\mathrm{cm})$ and $D_{\mathrm{b}}$ is the diameter of growth zone in the control dish $(\mathrm{cm})$.

The $\mathrm{IC}_{50}$ values (the concentration inhibited $50 \%$ of the mycelium growth) were calculated by probit analysis. Minimal inhibitory concentrations (MICs) were also examined using the methods reported by Kubo and Lee (1998) with slight modifications. Solutions of different concentrations of the test compounds were added to the sterilized PDA media. After inoculating the mycelium of fungal strains, the testing dishes were then incubated under the same growth conditions as above. When the mycelium of fungi reached the edges of the control dishes, the lowest concentration with no sign of growth was defined as MIC.

\subsection{Scanning electron microscopy}

For scanning electron microscopy (SEM) observation, the procedure was described by $\mathrm{Wu}$ et al. (2006). Mycelia $(0.1 \mathrm{~g})$ removed from agar surface were treated with $\beta$-thujaplicin at $50 \mu \mathrm{g} / \mathrm{ml}$ for $30 \mathrm{~min}$ prior to the SEM preparation. Treated mycelia and control were fixed in $2.5 \%$ glutaraldehyde (Sigma, USA) in a $0.1 \mathrm{M}$ phosphate buffer at $\mathrm{pH} 7.2$ at room temperature for $2 \mathrm{~h}$, washed three times with buffer, and post-fixed in 1\% osmium tetroxide (Sigma, USA) in the same buffer for $3 \mathrm{~h}$. The specimens were then rinsed three times with buffer, dehydrated through an acetone series (each step 20-30 min). The dehydrated materials were further dried with a Hitachi Critical Point Dryer (HCP-1). A coating of about $30 \mathrm{~nm}$ was made with IB-2 ion coater and examined by a Hitachi S-2400 SEM.

\subsection{Statistical analyses}

All results were expressed as mean $\pm \mathrm{SE}(n=5)$. The significance of difference among individual mean was determined by Scheffe's multiple comparison procedure in SAS. Results with $P<0.05$ were considered to be statistically significant difference.

\section{Results and discussion}

\subsection{Antifungal activities of ethanolic extract and subfractions}

Wood decay fungi, L. betulina and L. sulphureus were used to evaluate the antifungal potential of each partitioned fraction. The results of antifungal tests showed that the $n$-hexane soluble fraction processed the most significant antifungal activity among three partitioned fractions against $L$. betulina and $L$. sulphureus, while other fractions did not show antifungal activity at the same concentration $(500 \mu \mathrm{g} / \mathrm{ml})$. The $n$-hexane soluble fraction was further divided into 20 subfractions by liquid chromatography with silica gel 60 (Merck, Darmstadt, Germany) in an open column eluted with gradient $n-\mathrm{C}_{6} \mathrm{H}_{14} /$ EtOAc from $98 / 2$ to $0 / 100$. Twenty subfractions were screened for their antifungal activities at the concentration of $50 \mu \mathrm{g} / \mathrm{ml}$, and the results are shown in Fig. 1. Among the 20 subfractions, only fractions 4-13 exhibited antifungal effect. The subfractions 6-12 totally inhibited the growth of L. sulphureus, while the subfractions 7, 8 and 9 suppressed the growth of $L$. betulina for more than $95 \%$, indicating those subfractions consist of effective compounds. The tested concentrations were further diluted to determine which subfractions had the best antifungal effect. As the results shown in Fig. 2, at the concentration of $12.5 \mu \mathrm{g} / \mathrm{ml}$, subfraction 8 processed the strongest antifungal activity against $L$. betulina with antifungal index of $72 \%$ and followed by subfraction $9(71 \%)$. The similar results were also observed on the subfractions 8 and 9 which inhibited the growth of L. sulphureus for $63 \%$ and $61 \%$ at the concentration as low as $3.1 \mu \mathrm{g} / \mathrm{ml}$, respectively. Based on the results above, it is obvious that subfractions 8 and 9 were the most effective ones among all hexane subfractions. Therefore, the subfractions 8 and 9 were selected for compound isolation by high performance liquid chromatography (HPLC) and structural analysis by ${ }^{1} \mathrm{H}$ NMR and ${ }^{13} \mathrm{C}$ NMR.

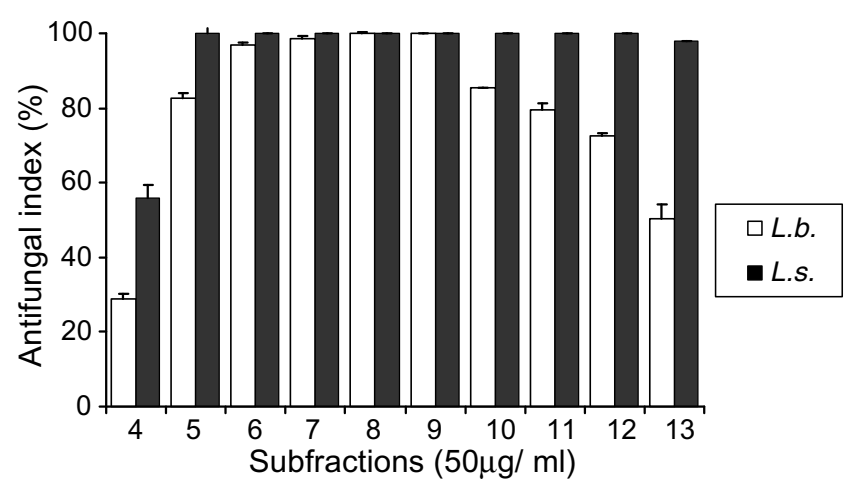

Fig. 1. Antifungal indices of hexane soluble subfractions 4-13 against Lenzites betulina and Laetiporus sulphureus at the concentration of $50 \mu \mathrm{g} /$ $\mathrm{ml}$.

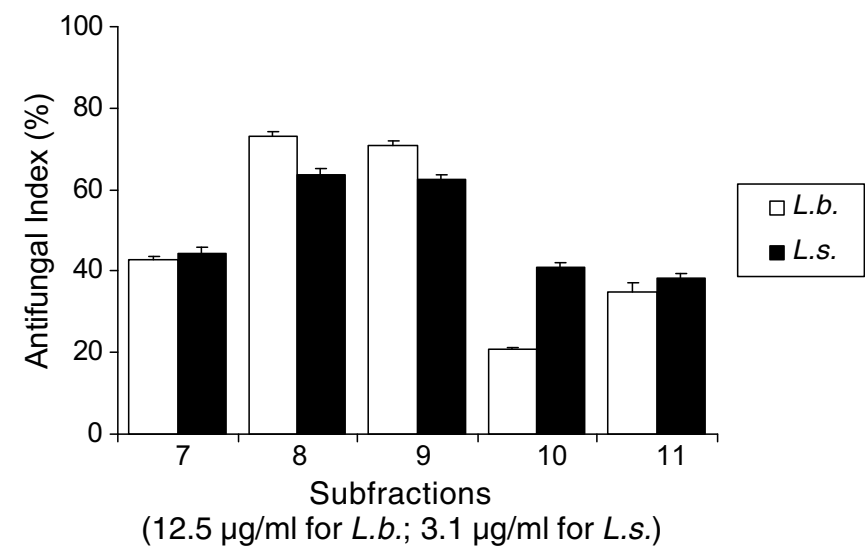

Fig. 2. Antifungal indices of hexane soluble subfractions 7-11 against Lenzites betulina $(12.5 \mu \mathrm{g} / \mathrm{ml})$ and Laetiporus sulphureus $(3.1 \mu \mathrm{g} / \mathrm{ml})$. 


\subsection{Compounds isolation and identification}

The subfractions 8 and 9 were combined prior to the isolation using high performance liquid chromatography (HPLC) based on the identical results of thin layer chromatography (TLC) with silica-60. HPLC was carried out by using the Hitachi L-7100 and RI detector L-74900 with Hibra Lichrosorb Si-60 column $(250 \mathrm{~mm} \times 10 \mathrm{~mm} \psi)$ and condition $\left(n-\mathrm{C}_{6} \mathrm{H}_{14}: \mathrm{EtOAc}=8: 2\right.$, flow speed $=4.0 \mathrm{ml} /$ $\min , 25^{\circ} \mathrm{C}$ ). Two significant peaks (retention time $=18.24$ $\mathrm{min}$ and $19.54 \mathrm{~min}$ ) were detected and collected, namely C-3 and C-4, which were purified by repeating the HPLC process at the same conditions twice prior to NMR analysis. C-3 and C-4 were identified to be $\beta$-thujaplicin and $\gamma$-thujaplicin based on the spectra of ${ }^{1} \mathrm{H}$ NMR and ${ }^{13} \mathrm{C}$ NMR as well as by comparisons with published data (Soung et al., 2000; Morita et al., 2001; Jang et al., 2005).

Although, thujaplicins have been isolated from several cupressaceous trees, including Thujopsis dolabrata var. hondai Makino, Thuja plicata, Thuja standishii Carr., and Chamaecyparis formosensis Mutsum (Baya et al., 2001; Danels and Russell, 2007; Jang et al., 2005). To our best knowledge, this is the first study to report the isolation of antifungal compounds, $\beta$-thujaplicin and $\gamma$-thujaplicin, from the heartwood of C. macrolepis var. formosana in Taiwan.

\subsection{Antifungal activities of $\beta$-thujaplicin and $\gamma$-thujaplicin against wood decay fungi}

To elucidate the antifungal activities and spectrum of $\beta$ thujaplicin and $\gamma$-thujaplicin, $\beta$-thujaplicin and $\gamma$-thujaplicin were evaluated by agar dilution assay against four white rot fungi, L. betulina, $P$. coccineus, $T$. versicolor and $S$. commune, and four brown rot fungi, $L$. sulphureus, $P$. schweinitzii, G. trabeum and $F$. pinicola. The antifungal test results showed that $\beta$-thujaplicin and $\gamma$-thujaplicin processed extremely strong antifungal activities against eight wood rotting fungi. The inhibitory effect was increased with increasing the concentration, indicating that the antifungal activities of $\beta$-thujaplicin and $\gamma$-thujaplicin were dosage-dependant.

The $\mathrm{IC}_{50}$ and MIC values of $\beta$-thujaplicin and $\gamma$-thujaplicin were determined and listed in ascending order in Table 1. In general, $\beta$-thujaplicin exhibited better inhibitory effect on the growth of wood decay fungi than those of $\gamma$-thujaplicin on the basis of $\mathrm{IC}_{50}$, but no significant differences were observed between their MIC values against L. betulina, L. sulphureus, P. schweinitzii and G. trabeum. The $\mathrm{IC}_{50}$ values of $\beta$-thujaplicin and $\gamma$-thujaplicin ranged from 0.2 to $3.3 \mu \mathrm{g} / \mathrm{ml}$ and 0.6 to $7.4 \mu \mathrm{g} / \mathrm{ml}$ against brown rot fungi, and ranged from 2.2 to $18.6 \mu \mathrm{g} / \mathrm{ml}$ and 7.9 to $24.2 \mu \mathrm{g} / \mathrm{ml}$ against white rot fungi, respectively, demonstrating that brown rot fungi, except $F$. pinicola, are more susceptible to both compounds than white rot fungi. In addition, among all test wood rotting fungi, $S$. commune showed the highest drug resistance to $\beta$-thujaplicin and $\gamma$ thujaplicin, while L. sulphureus was the most vulnerable.
Table 1

$\mathrm{IC}_{50}(\mu \mathrm{g} / \mathrm{ml})$ and MIC $(\mu \mathrm{g} / \mathrm{ml})$ values of $\beta$-thujaplicin and $\gamma$-thujaplicin against wood decay fungi, tree pathogenic fungi and molds $(n=5)$

\begin{tabular}{|c|c|c|c|c|}
\hline \multirow[t]{2}{*}{ Fungal strains } & \multicolumn{2}{|l|}{$\beta$-Thujaplicin } & \multicolumn{2}{|l|}{$\gamma$-Thujaplicin } \\
\hline & $\mathrm{IC}_{50}$ & MIC & $\mathrm{IC}_{50}$ & MI \\
\hline \multicolumn{5}{|l|}{ White rot } \\
\hline Lenzites betulina & $2.2 \pm 0.2^{\mathrm{a}}$ & 10.0 & $7.9 \pm 0.3^{\mathrm{a}}$ & 10.0 \\
\hline Pycnoporus coccineus & $8.7 \pm 0.2^{\mathrm{b}}$ & 15.0 & $12.1 \pm 2.0^{\mathrm{b}}$ & 25.0 \\
\hline Trametes versicolor & $14.4 \pm 0.3^{\mathrm{c}}$ & 25.0 & $16.5 \pm 2.6^{\mathrm{c}}$ & 30.0 \\
\hline Schizophyllum commune & $18.6 \pm 0.3^{\mathrm{d}}$ & 35.0 & $24.2 \pm 2.8^{\mathrm{d}}$ & 40.0 \\
\hline \multicolumn{5}{|l|}{ Brown rot } \\
\hline Laetiporus sulphureus & $0.2 \pm 0.1^{\mathrm{a}}$ & 5.0 & $0.6 \pm 0.5^{\mathrm{a}}$ & 5.0 \\
\hline Phaeolus schweinitzii & $0.8 \pm 0.2^{\mathrm{b}}$ & 5.0 & $1.4 \pm 1.0^{\mathrm{b}}$ & 10.0 \\
\hline Gloeophyllum trabeum & $1.2 \pm 0.3^{\mathrm{b}}$ & 10.0 & $2.3 \pm 1.1^{\mathrm{b}, \mathrm{c}}$ & 10.0 \\
\hline Fomitopsis pinicola & $3.3 \pm 0.4^{\mathrm{d}}$ & 10.0 & $7.4 \pm 1.2^{\mathrm{c}}$ & 15.0 \\
\hline \multicolumn{5}{|l|}{ Tree pathogenic fungi } \\
\hline Ganoderma australe & $3.2 \pm 0.2^{\mathrm{a}}$ & 10.0 & $6.7 \pm 0.8 \mathrm{a}$ & 15.0 \\
\hline Pestalotiopsis funerea & $17.7 \pm 1.5^{\mathrm{b}}$ & 25.0 & $20.5 \pm 2.1^{\mathrm{b}}$ & 35.0 \\
\hline Fusarium solani & $18.1 \pm 1.6^{\mathrm{b}, \mathrm{c}}$ & 40.0 & $23.6 \pm 2.2^{\mathrm{b}}$ & 45.0 \\
\hline $\begin{array}{l}\text { Colletotrichum } \\
\text { gloeosporioides }\end{array}$ & $22.3 \pm 1.8^{\mathrm{c}}$ & 45.0 & $23.8 \pm 2.4^{\mathrm{b}}$ & 50.0 \\
\hline \multicolumn{5}{|l|}{ Mold } \\
\hline Trichoderma viride & $10.2 \pm 1.7^{\mathrm{a}}$ & 20.0 & $14.8 \pm 1.8^{\mathrm{a}}$ & 25.0 \\
\hline Penicillium citrinum & $14.3 \pm 1.8^{\mathrm{b}}$ & 30.0 & $17.6 \pm 1.7^{\mathrm{a}}$ & 30.0 \\
\hline Aspergillus niger & $24.5 \pm 2.0^{\mathrm{c}}$ & 50.0 & $26.5 \pm 2.7^{\mathrm{b}}$ & 50.0 \\
\hline
\end{tabular}

MIC value of propiconazole which was used as a comparison against $L$. sulphureus was $1.2 \mu \mathrm{g} / \mathrm{ml}$. The $\mathrm{IC}_{50}$ values with different superscript letters in the same column of the same fungal group are significantly different at alpha level of 0.05 .

Antifungal activity of $\beta$-thujaplicin and $\gamma$-thujaplicin on the tree rotting fungus, Daedalea dickinsii, has been reported (Inamori et al., 2000). Baya et al. (2001) also indicated that $\beta$-thujaplicin strongly inhibited the growth of four wood rotting fungi at $100 \mu \mathrm{M}$. Their observations are in agreement with our results, indicating $\beta$-thujaplicin and $\gamma$-thujaplicin have outstanding antifungal activity and broad antifungal spectrum against wide variety of wood decay fungi.

Similar drug response curves of $\beta$-thujaplicin based on serial concentrations against $L$. betulina and $L$. sulphureus were observed (Fig. 3). The antifungal effect increased more dramatically as the dosage increased in the beginning. On the contrary, the drug response of $\gamma$-thujaplicin behaved in the opposite manner. The antifungal effect did not increase until reaching a higher concentration in the testing dosage range (Fig. 4). These differences of response curves between $\beta$-thujaplicin and $\gamma$-thujaplicin could explain why the $\beta$-thujaplicin had lower $\mathrm{IC}_{50}$ values than $\gamma$-thujaplicin against the same fungus tested.

\subsection{Antifungal activities of $\beta$-thujaplicin and $\gamma$-thujaplicin against tree pathogenic fungi}

$\beta$-Thujaplicin and $\gamma$-thujaplicin were further evaluated for their antifungal activities against four tree pathogenic fungi. Excellent antifungal activities were observed and all test fungi were totally inhibited by $\beta$-thujaplicin and 


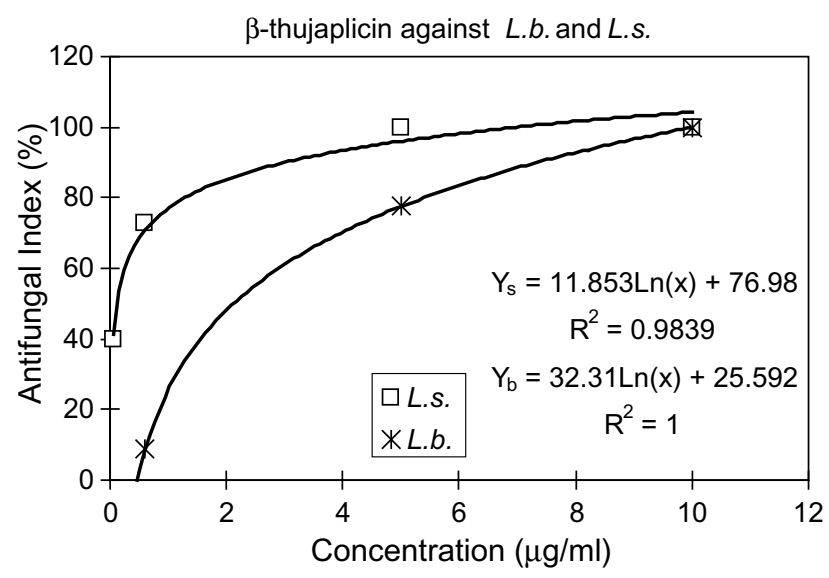

Fig. 3. Response curves of $\beta$-thujaplicin against Laetiporus sulphureus and Lenzites betulina ( $Y_{\mathrm{s}}$ and $Y_{\mathrm{b}}$ : the regression equations for $L$. sulphureus and $L$. betulina, respectively).

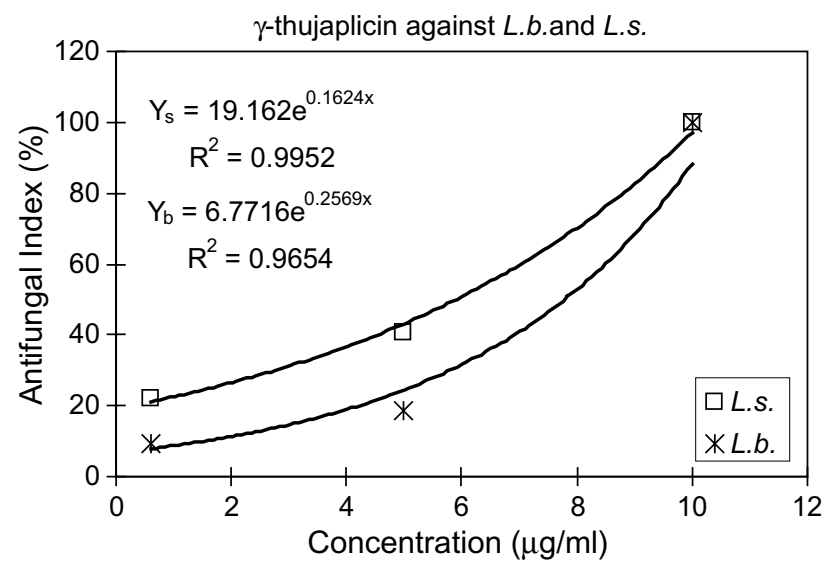

Fig. 4. Response curves of $\gamma$-thujaplicin against Laetiporus sulphureus and Lenzites betulina ( $Y_{\mathrm{s}}$ and $Y_{\mathrm{b}}$ : the regression equations for L. sulphureus and $L$. betulina, respectively).

$\gamma$-thujaplicin at the concentration of $50 \mu \mathrm{g} / \mathrm{ml}$ with no sign of recovery after two weeks of inoculation. The $\mathrm{IC}_{50}$ and MIC values were determined as shown in Table 1 . The $\mathrm{IC}_{50}$ values of $\beta$-thujaplicin and $\gamma$-thujaplicin ranged from 3.2 to $22.3 \mu \mathrm{g} / \mathrm{ml}$ and 6.7 to $23.8 \mu \mathrm{g} / \mathrm{ml}$, and the MIC values of $\beta$-thujaplicin and $\gamma$-thujaplicin ranged from 10.0 to $45.0 \mu \mathrm{g} / \mathrm{ml}$ and 15.0 to $50.0 \mu \mathrm{g} / \mathrm{ml}$, respectively. Compared with the results on the wood rotting fungi, $\beta$-thujaplicin also performed better than $\gamma$-thujaplicin against the same pathogenic fungi in the tests. Meanwhile, the potencies of antifungal activities of $\beta$-thujaplicin and $\gamma$-thujaplicin were in the same descending order (G. australe $>P$. funerea $>F$. solani $>C$. gloeosporioides). The antifungal properties of $\beta$ thujaplicin and hinokitiol related compounds against plant pathogenic fungi have been reported by Morita et al. (2003, 2004). Although their test fungi were different to the pathogenic fungi in our study, both results demonstrated that $\beta$ thujaplicin and $\gamma$-thujaplicin were very effective against wide variety of plant pathogenic fungi.

\subsection{Antifungal activities of $\beta$-thujaplicin and $\gamma$-thujaplicin against molds}

The results of antifungal tests were summarized in Table 1. $\beta$-Thujaplicin showed excellent antifungal activities with $\mathrm{IC}_{50}$ and MIC values in the ranges of $10.2-24.5 \mu \mathrm{g} / \mathrm{ml}$ and $20.0-50.0 \mu \mathrm{g} / \mathrm{ml}$, respectively. In comparison, the antifungal activities of $\gamma$-thujaplicin were similar to those of $\beta$-thujaplicin. The $\mathrm{IC}_{50}$ and MIC values of $\gamma$-thujaplicin were in the ranges of $14.8-26.5 \mu \mathrm{g} / \mathrm{ml}$ and $25-50.0 \mu \mathrm{g} / \mathrm{ml}$, respectively. Fungus such as $T$. viride was totally inhibited by $\beta$-thujaplicin at the concentration as low as $20 \mu \mathrm{g} / \mathrm{ml}$. The results showed that $\beta$-thujaplicin and $\gamma$-thujaplicin effectively inhibited the growth of molds, showing enormous potential in preventing the deterioration of paper products as well as controlling the mycotoxic fungi that cause health problems.

\subsection{Antifungal mechanisms of $\beta$-thujaplicin and $\gamma$-thujaplicin}

The mechanisms of antifungal effects of $\beta$-thujaplicin and $\gamma$-thujaplicin could be primarily attributed to the change on the cell wall permeability leading cytoplasm leakage and the metal chelation interrupting the fungal enzymatic process. Structurally, the fungal cell wall is composed of a matrix of proteins and polycarbohydrates. Disrupting this matrix can result in a malfunctioning cell wall, which becomes sensitive to osmotic lysis and susceptive to fungicides. The metal chelating property of $\beta$-thujaplicin has been shown previously to reduce the activities of laccase, tyrosinase and lipoxygenase by chelating crucial metal ions involved in those enzymatic processes (Poma et al., 1999; Suzuki et al., 2000). Furthermore, the metal chelating properties associated of the hydroxyl group and the position of isopropyl group on $\beta$-thujaplicin have also been preliminarily investigated by replacing the hydroxyl group with a methoxy or a benzyloxy group (Baya et al., 2001). It was found that the derivative was less effective than $\beta$-thujaplicin in terms of antifungal activities and iron chelating ability. On the other hand, the position of isopropyl group did not dramatically affect the antifungal activity. The position effect of isopropyl group can be confirmed by the similar antifungal activities of $\beta$-thujaplicin and $\gamma$-thujaplicin.

In addition, the structural change of fungal hyphae treated with $\beta$-thujaplicin was further examined by scanning electron microscopy (SEM). Mycelia $(0.1 \mathrm{~g})$ of $L$. sulphureus removed from agar surface were treated with $\beta$-thujaplicin at the concentration of $50 \mu \mathrm{g} / \mathrm{ml}$ for 30 min prior to the SEM process. In comparison to the control group, severe cell wall collapse was observed on the hyphae and terminal chlamydospore of treated group, indicating that fungal cell wall might be disintegrated and leading massive cytoplasm leakage. However, the evidence of SEM is limited to thoroughly clarify the destruction process on the fungal cell wall structures and the role of metal chelating effect in antifungal activity of two thujaplicins. Further studies by 
transmitted electron microscopy with immunological labeling or biophysical methods are needed.

\section{Conclusions}

In conclusion, two antifungal compounds from the ethanolic extracts of $C$. macrolepis var. formosana heartwood were isolated and identified as $\beta$-thujaplicin and $\gamma$-thujaplicin. Antifungal activities of those two compounds were evaluated against 15 different fungi. Results demonstrated that $\beta$-thujaplicin and $\gamma$-thujaplicin exhibited very strong antifungal activity and board antifungal spectrum against wide variety of fungi such as wood decay fungi, tree pathogenic fungi and molds. Meanwhile, $\beta$-thujaplicin performed better than $\gamma$-thujaplicin on most fungi. Among the test fungi, the brown rot fungus, L. sulphureus, was the most vulnerable to $\beta$-thujaplicin and $\gamma$-thujaplicin. Its growth can be totally inhibited by $\beta$-thujaplicin with MIC values as low as $5.0 \mu \mathrm{g} / \mathrm{ml}$, which is nearly comparable to the effect of commercial fungicide, propiconazole $(\mathrm{MIC}=1.2 \mu \mathrm{g} / \mathrm{ml})$. In addition, the antifungal properties of $\beta$-thujaplicin and $\gamma$-thujaplicin could be attributed to the combined effects of metal chelating and cytoplasm leakage. Especially the role of metal chelating should receive more attention in the development of environmentalfriendly fungicides. The results clearly demonstrated that $\beta$-thujaplicin and $\gamma$-thujaplicin have the potential to be developed as multiple-purposes fungicides in protecting wood and paper products as well as preventing plant diseases associated with fungi. However, these results are the laboratory findings which will call for field investigation to facilitate the practical use, and these compounds are also required further study to elucidate their antifungal mechanisms for pharmaceutical application.

\section{Acknowledgements}

Funding for this study was provided by the National Science Council of Taiwan (NSC-93-2313-B-002-014). A special gratitude is extended to Dr. Chi-I. Chang at the National Pingtung University of Science and Technology, Taiwan, for his assistance.

\section{References}

Asada, T., Ishimoto, T., Sakai, A., Sumiya, K., 1989. Insecticidal and antifungal activity in hinoki-asunaro leaf oil. Mokuzai Gakkaishi 35, 851-855.

Baya, M., Soulounganga, P., Gelhaye, E., Gerardin, P., 2001. Fungicidal activity of $\beta$-thujaplicin analogues. Pest Manage. Sci. 57, 833 838.

Chang, S.T., Cheng, S.S., 2002. Antitermite activity of leaf essential oils and their constituents from Cinnamomum osmophloeum. J. Agric. Food Chem. 50, 1389-1392.

Chang, S.T., Wu, C.L., Wang, S.Y., Su, Y.C., Kuo, Y.H., 1998. Studies on the antifungal compounds in the heartwood extractives of Taiwania (Taiwania cryptomerioides Hayata) (I): isolation and identification of antifungal compounds in hexane soluble fraction. For. Prod. Ind. 17, 287-304.
Chang, S.T., Wang, S.Y., Wu, C.L., Su, Y.C., Kuo, Y.H., 1999. Antifungal compounds in the ethyl acetate soluble fraction of the extractives of Taiwania (Taiwania cryptomerioides Hayata) heartwood. Holzforschung 53, 487-490.

Chang, S.T., Wang, S.Y., Wu, C.L., Chen, P.F., Kuo, Y.H., 2000. Comparison of the antifungal activity of cadinane skeletal sesquiterpenoids from Taiwania (Taiwania cryptomerioides Hayata) heartwood. Holzforschung 54, 241-245.

Chang, S.T., Cheng, S.S., Wang, S.Y., 2001. Antitermitic activity of essential oils and components from Taiwania (Taiwania cryptomerioides). J. Chem. Ecol. 27, 717-724.

Cheng, S.S., Chang, S.T., 2002. Antitermitic activity of essential oils from Cryptomeria japonica Q. J. Chin. For. 35, 193-199.

Cheng, Y.S., Lo, T.B., Chang, L.H., Lin, Y.T., 1961. Study of the extractives constituents from the wood of Libocedrus formosana Florin. IV. Partial hydrogenation of thujic acid. J. Chin. Chem. Soc. 8, 103-108.

Cheng, S.S., Wu, C.L., Chang, H.T., Kao, Y.T., Chang, S.T., 2004. Antitermitic and antitermitic activity of essential oil of Calocedrus formosana leaf and its composition. J. Chem. Ecol. 10, 1957-1967.

Cheng, S.S., Liu, J.Y., Hsui, Y.R., Chang, S.T., 2006. Chemical polymorphism and antifungal activity of essential oils from leaves of different provenances of indigenous cinnamon (Cinnamomum osmophloeum). Bioresour. Technol. 97, 306-312.

Danels, C.R., Russell, J.H., 2007. Analysis of western redcedar (Thuja plicata Donn) heartwood components by HPLC as a possible screening tool for trees with enhanced natural durability. J. Chromatogr. Sci. 45 (5), 281-285.

Fang, J.M., Jan, S.T., Cheng, T.S., 1985. (+)-Calocedrin, a lignan dehydroanhydride from Calocedrus formosana. Phytochemistry 24, $1863-1864$.

Fang, J.M., Jan, S.T., Cheng, T.S., 1987. Terpenoids from Calocedrus formosana. Phytochemistry 26, 853-854.

Fang, J.M., Hsu, K.C., Cheng, Y.S., 1989. Lignans from leaves of Calocedrus formosana. Phytochemistry 28, 3553-3555.

Hart, J.H., 1989. The role of wood exudates and extractives in protecting wood from decay. In: Rowe, J.W. (Ed.), Natural Products of Woody Plants. Springer-Verlag Co., Berlin, pp. 861-878.

Hsieh, C.L., Shiu, L.L., Tseng, M.H., Shao, Y.Y., Kuo, Y.H., 2006. Calocedimers A, B, C, and D form the bark of Calocedrus macrolepis var. formosana. J. Nat. Prod. 69 (4), 665-667.

Inamori, Y., Sakagami, Y., Morita, Y., Shibata, M., Sugiura, M., Kumeda, Y., Okabe, T., Tsujibo, H., Ishida, N., 2000. Antifungal activity of hinokitol-related compounds on wood-rotting fungi and their insecticidal activities. Biol. Pharm. Bull. 23, 995-997.

Jang, Y.S., Lee, C.H., Kim, M.K., Kim, J.H., Lee, S.H., Lee, H.S., 2005. Acaridal activity of active constituent isolated in Chamaecyparis obtusa leaves against Dermatophagoides spp. J. Agric. Food Chem. 53, 1934 1937.

Kai, Y., 1991. Chemistry of extractives. In: Hon, D.N.S., Shiraish, N. (Eds.), Wood and Cellulosic Chemistry. Marcell Dekker Inc., New York, pp. 215-255.

Kinjo, K., Yata, S., 1986. Study on the cultivation culture media of basidiomycetes. IV. Antifungal activity of hinoki. Mokuzai Gakkaishi 32, 632-636.

Kishino, M., Ohi, H., Yamaguchi, A., 1995. Characteristics of methanol extractives from chengal wood and their antifungal properties. Mokuzai Gakkaishi 41, 444-447.

Kondo, R., Imamura, H., 1986. Antifungal compounds in heartwood extractives of hinoki (Chamaecyparis obtusa Endl.). Mokuzai Gakkaishi 32, 213-217.

Kubo, I., Lee, S.H., 1998. Potentiation of antifungal activity of sorbic acid. J. Agric. Food Chem. 46, 4052-4055.

Lin, Y.T., Lo, T.B., Lin, T.H., 1956. Study of the extractives constituents from the wood of Libocedrus formosana Florin. II. Interconversion between isoshonanic acid and thujic acid. J. Chin. Chem. Soc. 3, 36-40.

Lo, T.B., Lin, Y.T., 1956. Study of the extractives constituents from the wood of Libocedrus formosana Florin. I. J. Chin. Chem. Soc. 3, 30-35. 
Morita, S.I., Hidaka, T., Yatagai, M., 1997. Antifungal components of the extractives of yakusugi (Crypotomeria japonica D. Don). Wood Preserv. 23, 11-19.

Morita, Y., Matsumura, E., Tsujibo, H., Yasuda, M., Sakagami, Y., Okabe, T., Ishida, N., Inamori, Y., 2001. Biological activity of $\alpha$ thujaplicin, the minor component of Thujopsis dolabrata Sieb. et Zucc. var. hondai Makino. Biol. Pharm. Bull. 24 (6), 607-611.

Morita, Y., Matsumura, E., Okabe, T., Fukui, T., Shibata, M., Sugiura, M., Ohe, T., Tsujibo, H., Ishida, N., Inamori, Y., 2003. Bioactivity of tropolone. Biol. Pharm. Bull. 26 (10), 1487-1490.

Morita, Y., Matsumura, E., Okabe, T., Fukui, T., Shibata, M., Sugiura, M., Ohe, T., Ishida, N., Inamori, Y., 2004. Biological activity of $\alpha$ thujaplicin, the isomer of hinokitiol. Biol. Pharm. Bull. 27 (6), 899-902.

Nabeta, K., Katayama, K., Matsubara, M., Hatakeyama, C., Shimada, T., Tazaki, H., Okuyama, H., Miyake, M., 1992. Oxygenated sesquiterpenes from needles of Korean pine (Pinus Koraiensis Sieb. et Zucc.). Mokuzai Gakkaishi 38, 963-971.

Poma, A., Pacioni, G., Colafarina, S., Miranda, M., 1999. Effect of tyrosinase inhibitors on Tuber borchii mycelium growth in vitro. FEMS Microbiol. Lett. 180, 69-75.
Rudman, P., 1965. The causes of natural durability in timber. XVIII. Further notes on the fungi toxicity of wood extractives. Holzforschung 19, 57-58.

Schultz, T.P., Nicholas, D.D., 2000. Naturally durable heartwood: evidence for a proposed dual defensive function of the extractives. Phytochemistry 54, 47-52.

Soung, M.G., Matsui, M., Kitahara, T., 2000. Regioselective synthesis of $\beta$ - and $\gamma$-thujaplicins. Tetrahedron 56 (39), 7741-7745.

Suzuki, H., Ueda, T., Juranek, I., Yamamoto, S., Katoh, T., Node, M., Suzuki, T., 2000. Hinokitiol, a selective inhibitor of the platelet type isozyme of arachidonate 12-lipoxygenase. Biochem. Biophys. Res. Commun. 275, 885-889.

Wang, S.Y., Chen, P.F., Chang, S.T., 2005. Antifungal activities of essential oils and their constituents from indigenous cinnamon (Cinnamomum osmophloeum) leaves against wood decay fungi. Bioresour. Technol. 96, 813-818.

Wu, C.C., Chen, S.J., Yen, T.B., Kuo-huang, L.L., 2006. Influence of calcium availability on deposition of calcium carbonate and calcium oxalate crystals in the idioblasts of Morus australis Porir. leaves. Bot. Stud. 47, 119-127. 